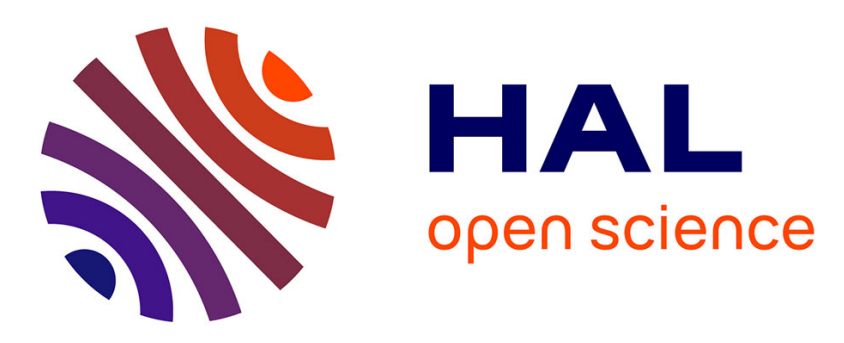

\title{
Low-Coordinate Barium Boryloxides: Synthesis and Dehydrocoupling Catalysis for the Production of Borasiloxanes
}

\author{
Erwann Le Coz, Vincent Dorcet, Thierry Roisnel, Sven Tobisch, J-F \\ Carpentier, Yann Sarazin
}

\section{To cite this version:}

Erwann Le Coz, Vincent Dorcet, Thierry Roisnel, Sven Tobisch, J-F Carpentier, et al.. LowCoordinate Barium Boryloxides: Synthesis and Dehydrocoupling Catalysis for the Production of Borasiloxanes. Angewandte Chemie International Edition, 2018, 57 (36), pp.11747-11751. 10.1002/anie.201807297 . hal-01862088

\section{HAL Id: hal-01862088}

https://hal-univ-rennes1.archives-ouvertes.fr/hal-01862088

Submitted on 26 Aug 2018

HAL is a multi-disciplinary open access archive for the deposit and dissemination of scientific research documents, whether they are published or not. The documents may come from teaching and research institutions in France or abroad, or from public or private research centers.
L'archive ouverte pluridisciplinaire HAL, est destinée au dépôt et à la diffusion de documents scientifiques de niveau recherche, publiés ou non, émanant des établissements d'enseignement et de recherche français ou étrangers, des laboratoires publics ou privés. 


\title{
Low-Coordinate Barium Boryloxides: Synthesis and Dehydrocoupling Catalysis for the Production of Borasiloxanes
}

\author{
Erwann Le Coz, ${ }^{[a]}$ Vincent Dorcet,${ }^{[a]}$ Thierry Roisnel, ${ }^{[a]}$ Sven Tobisch, ${ }^{*[b]}$ Jean-François Carpentier, ${ }^{[a]}$ \\ and Yann Sarazin ${ }^{*[a]}$
}

\begin{abstract}
The first soluble barium boryloxides $[\mathrm{Ba}]-\mathrm{OB}\left\{\mathrm{CH}\left(\mathrm{SiMe}_{3}\right)_{2}\right\}$ are presented. These mono- or dinuclear complexes feature low coordination numbers, as low as two for $\left[\mathrm{Ba}\left(\mathrm{OB}\left\{\mathrm{CH}\left(\mathrm{SiMe}_{3}\right)_{2}\right\}_{2}\right)_{2}\right]$, which is further stabilized by intra- and intermolecular $\mathrm{Ba} \cdots \mathrm{H}_{3} \mathrm{C}$ agostic interactions. Ba-boryloxides and the parent $\left.\left[\mathrm{Ba}\left\{\mathrm{N}\left(\mathrm{SiMe}_{3}\right)_{2}\right\}_{2} \text {. (thf }\right)_{2}\right]$ catalyze the dehydrocoupling of borinic acids with hydrosilanes, providing borasiloxanes under mild conditions.
\end{abstract}

Complexes of the large alkaline earths $(=\mathrm{Ae})$ calcium, strontium and barium are increasingly used in molecular catalysis as alternatives to mainstream late transition metal catalysts. ${ }^{[1]}$ These developments can be paralleled with the many breakthroughs in the organometallic chemistry of calcium, ${ }^{[2-4]}$ while in comparison progress with strontium ${ }^{[5]}$ and barium ${ }^{[6]}$ has been slow owing to greater synthetic challenges. $\mathrm{Ca}^{2+}\left(r_{\text {ionic }}=\right.$ $1.00 \AA), \mathrm{Sr}^{2+}(1.18 \AA)$ and $\mathrm{Ba}^{2+}(1.35 \AA)$ are large, electropositive ions that generate highly ionic $d^{0}$ complexes. Despite their trademark reactivity that generally increases upon descending group 2, heteroleptic Ae complexes may be plagued by ligand scrambling. Hence, although they often demonstrate the best aptitude in catalysis, ${ }^{[1,7]}$ barium complexes can also suffer from excessive basicity, kinetic lability, and propensity to form polynuclear, insoluble species. ${ }^{[8]}$

Discrete molecular barium alkoxides are scarce. Barium is characterized by its large size, affinity for high ( 8 or more) coordination numbers, and pronounced oxophilicity and electropositivity. With regular alcohols, e.g. ${ }^{t} \mathrm{BuOH}$, it yields polymeric alkoxides of low solubility that sometimes decompose to oxoclusters. ${ }^{[9]}$ The first authenticated soluble $\mathrm{Ba}$-alkoxide was the 8-coordinate $\left[\mathrm{Ba}\left\{\mathrm{K}^{4}-\mathrm{N}\left(\mathrm{CH}_{2} \mathrm{CH}_{2} \mathrm{O}\right)\left(\mathrm{CH}_{2} \mathrm{CH}_{2} \mathrm{OH}\right)_{2}\right\}_{2}\right]^{[10]}$ The dinuclear $\left[\mathrm{Ba}_{2}\left(\mu^{2}-\mathrm{OCPh}_{3}\right)_{3}\left(\mathrm{OCPh}_{3}\right)(\text { thf })_{3}\right]$ was obtained from bulky $\mathrm{Ph}_{3} \mathrm{SiOH}^{[11]}$ while diethylene glycol returned $\left[\mathrm{Ba}\left\{\mathrm{K}^{3}\right.\right.$ $\left.\left.\mathrm{O}\left(\mathrm{CH}_{2} \mathrm{CH}_{2} \mathrm{O}\right)_{2}\right\}\left\{\mathrm{k}^{3}-\mathrm{O}\left(\mathrm{CH}_{2} \mathrm{CH}_{2} \mathrm{OH}\right)_{2}\right\}_{2}\right]$. ${ }^{[12]}$ The presence of $\mathrm{CF}_{3}$ groups in a position to the alkoxide stabilizes $\mathrm{Ba}-$ fluoroalkoxides. ${ }^{[13]}$ Siloxides are derivatives of alkoxides that produce mono- ${ }^{[14]}$ and dinuclear Ba species ${ }^{[12,15]}$ or even higher aggregates ${ }^{[16]}$ the seminal example being Caulton's $\left[\mathrm{Ba}_{2}\left(\mu^{2}-\right.\right.$ $\left.\left.\mathrm{OSi}^{t} \mathrm{Bu}\right)_{3}\right)_{3}\left(\mathrm{OSi}^{t} \mathrm{Bu} u_{3}\right)($ thf $\left.)\right]{ }^{[12]}$ Yet, nothing is known about $\mathrm{Ba}-$

[a] E. Le Coz, Dr. V. Dorcet, Dr. T. Roisnel, Prof. Dr. J-F. Carpentier, Dr. Y. Sarazin

Univ Rennes, CNRS, ISCR (Institut des Sciences Chimiques de

Rennes) - UMR 6226, F-35000 Rennes (France)

E-mail: yann.sarazin@univ-rennes1.fr

[b] Dr. S. Tobisch

School of Chemistry

University of St Andrews

Purdie Building, North Haugh, St Andrews KY16 9ST (UK)

E-mail: st40@st-andrews.ac.uk

Supporting information for this article is given via a link at the end of the document. boryloxides, in spite of occurrences for other main group metals, ${ }^{[17]}$ including magnesium. ${ }^{[18]}$ Due to delocalization of the $O$ atom lone pairs in the empty $p_{z}$ orbital at boron, boryloxides $\mathrm{R}_{2} \mathrm{BO}^{-}$may be seen as electron poor analogues of alkoxides, or even of ketones or ketyl radicals. On this account, and in conjunction with its great steric demands, we reasoned that $\left\{\left(\mathrm{Me}_{3} \mathrm{Si}\right)_{2} \mathrm{CH}\right\}_{2} \mathrm{BO}^{-}$should afford soluble, low coordinate, highly electrophilic and hence reactive barium species. This strategy met with success, and we report herein on the first $\mathrm{Ba}$ boryloxides, that exhibit low coordination numbers (2-4): $\left[\mathrm{Ba}\left\{\mathrm{OB}\left(\mathrm{CH}\left(\mathrm{SiMe}_{3}\right)_{2}\right)_{2}\right\}_{2}\right], \quad \mathrm{Ba}\left\{\mathrm{OB}\left(\mathrm{CH}\left(\mathrm{SiMe}_{3}\right)_{2}\right)_{2}\right\}_{2}$. (thf $\left.)_{2}\right], \quad$ and $\left[\mathrm{Ba}\left\{\mu^{2}-\mathrm{N}\left(\mathrm{SiMe}_{3}\right)_{2}\right\}\left\{\mathrm{OB}\left(\mathrm{CH}\left(\mathrm{SiMe}_{3}\right)_{2}\right)_{2}\right\}\right]_{2}$.

In addition, we reveal how these complexes, as well as their $\left.\left[\mathrm{Ba}\left\{\mathrm{N}\left(\mathrm{SiMe}_{3}\right)_{2}\right\}_{2} \text {.(thf }\right)_{2}\right]$ congener, catalyze the dehydrocoupling of borinic acids and hydrosilanes to yield borasiloxanes. These molecules containing [B-O-Si] motifs are precursors to borosilicate materials, ${ }^{[19]}$ heat and chemical resistant polymers, and polymer sensors. ${ }^{[20]}$ Classical routes to borasiloxanes imply the condensation of various boron- and silicon-based reagents, but they are not atom-efficient and often entail drawbacks such as release of toxic/corrosive wastes and lack of selectivity. ${ }^{[21]}$ Instead, a few catalyzed processes pairing silanols or hydrosilanes with hydroboranes, diboranes, boraxanes or vinylboronates were disclosed recently; they rely on late transition metal complexes ${ }^{[22]}$ or $\mathrm{Mo}(\mathrm{CO})_{6} \cdot{ }^{[23]}$ None involves a main group metal catalyst, a dehydrocoupling procedure, or the utilization of borinic acids. Such methodology is unveiled here, and preliminary kinetic and mechanistic insights are also provided.

The thf solvate $\left.\left[\mathrm{Ba}\left(\mathrm{OB}\left\{\mathrm{CH}\left(\mathrm{SiMe}_{3}\right)_{2}\right\}_{2}\right)_{2} \text {.(thf }\right)_{2}\right]$ (2.(thf $)_{2}$; See the Supporting Information for its XRD structure) was obtained in near quantitative yield upon reaction of the borinic acid $\left\{\left(\mathrm{Me}_{3} \mathrm{Si}\right)_{2} \mathrm{CH}\right\}_{2} \mathrm{BOH} \quad\left(\mathrm{R}_{2} \mathrm{BOH}\right)$ with $\left.\left[\mathrm{Ba}\left\{\mathrm{N}\left(\mathrm{SiMe}_{3}\right)_{2}\right\}_{2} \text {. (thf }\right)_{2}\right] \quad$ (1, Scheme 1). This mononuclear complex, the first barium boryloxide, cannot be isolated free of thf by this protocol. The heteroleptic dimer $\left[\mathrm{Ba}\left\{\mu^{2}-\mathrm{N}\left(\mathrm{SiMe}_{3}\right)_{2}\right\}\left(\mathrm{OB}\left\{\mathrm{CH}\left(\mathrm{SiMe}_{3}\right)_{2}\right\}_{2}\right)\right]_{2}(3)$ was prepared in $85 \%$ yield by equimolar reaction of 1 and $\mathrm{R}_{2} \mathrm{BOH}$. Treatment of 3 with 2 equiv of $\mathrm{R}_{2} \mathrm{BOH}$ in petroleum ether afforded $\left[\mathrm{Ba}\left(\mathrm{OB}\left\{\mathrm{CH}\left(\mathrm{SiMe}_{3}\right)_{2}\right\}_{2}\right)_{2}\right]$ (2), a unique two-coordinate barium complex (Scheme 1). Considering the oxophilicity and natural $\pi$-donating ability of oxygen atoms in the chemistry of oxophilic metals, the relative ease of synthesis, stability and good solubility of $\mathbf{2}$ are remarkable. All three complexes are airsensitive colorless solids, with excellent solubility in common organic solvents, including aliphatic hydrocarbons.

The solid-state structure of the centro-symmetric dimer 3 presents remarkable features, notably a rare ${ }^{[24]}$ three-coordinate environment about the metals with a rhomboidal $\mathrm{Ba}_{2} \mathrm{~N}_{2}$ central core and boryloxides in terminal positions (Figure 1) 
$\left[\mathrm{Ba}\left\{\mathrm{N}\left(\mathrm{SiMe}_{3}\right)_{2}\right\}_{2} \cdot(\text { thf })_{2}\right]$

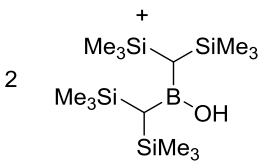<smiles>[Mg][Mg][Mg]</smiles><smiles>[R10]O[B-](O[R10])(OC)OC1CCCC1</smiles>
2.(thf) $)_{2}$

$\left(\mathrm{R}_{2} \mathrm{BOH}\right)$ $\underset{\text { [oluene }}{\left.\left[\mathrm{Ba}\left\{\mathrm{N}\left(\mathrm{SiMe}_{3}\right)_{2}\right\}_{2} \text {. (thf }\right)_{2}\right]} \downarrow-4$ thf

$2\left[\mathrm{Ba}\left\{\mathrm{N}\left(\mathrm{SiMe}_{3}\right)_{2}\right\}_{2} \cdot(\text { thf })_{2}\right]$ $+2 \mathrm{R}_{2} \mathrm{BOH}$

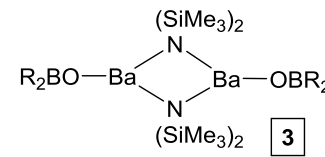<smiles>[R20]NCCC(C)(C)CC(C)(C)C</smiles>

$2 \mathrm{R}_{2} \mathrm{BO}-\mathrm{Ba}_{2}-\mathrm{OBR}_{2}$

Scheme 1. Syntheses of low-coordinate [Ba]-boryloxides.

In related cases of supported heteroleptic amido/alkoxo barium dimers, the dinuclear edifices are bridged through the $\mathrm{O}_{\text {alkoxide }}$ atoms. ${ }^{[15,25]}$ The bonding situation in $\mathbf{3}$ reflects both considerable steric bulk of the boryloxide $\mathrm{R}_{2} \mathrm{BO}^{-}$and limited electronic density available at $\mathrm{O}_{\text {boryloxide }}$ to bridge the two metals. The geometry about $\mathrm{Ba} 1$ is distorted trigonal planar $\left(\Sigma_{\theta}(\mathrm{Ba} 1)=348.2^{\circ}\right)$. The $\mathrm{N} 1-\mathrm{Ba} 1-\mathrm{N} 1^{\mathrm{i}}$ angle of $82.34(5)^{\circ}$ in 3 correlates to that in $\left[\mathrm{Ba}\left\{\mu^{2}-\right.\right.$ $\left.\left.\mathrm{N}\left(\mathrm{SiMe}_{3}\right)_{2}\right\}\left\{\mathrm{N}\left(\mathrm{SiMe}_{3}\right)_{2}\right\}\right]_{2} \quad\left(81.89(11)^{\circ}\right) .{ }^{[24 a]}$ The $\mathrm{Ba}-\mathrm{N}_{\text {bridge }}$ distances in this complex are commensurate (2.799(4) and 2.846(4) $\AA$ ), but they deviate much in 3 (2.721(2) and 2.891(2) A).

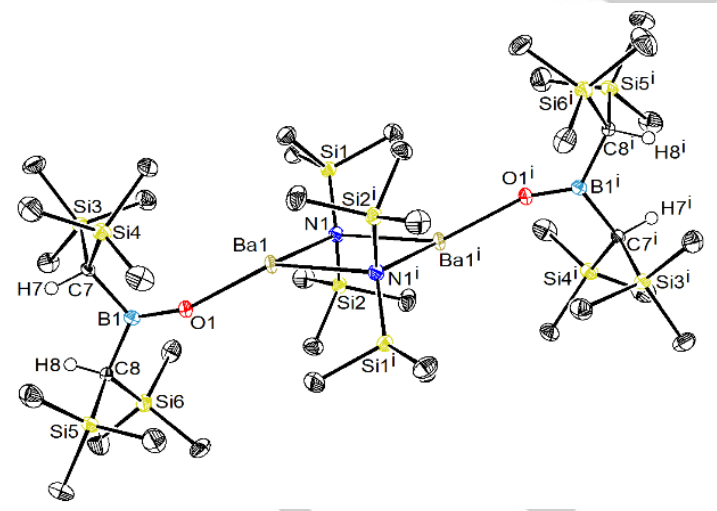

Figure 1. ORTEP representation of $\left[\mathrm{Ba}\left\{\mu^{2}-\mathrm{N}\left(\mathrm{SiMe}_{3}\right)_{2}\right\}\left(\mathrm{OB}\left\{\mathrm{CH}\left(\mathrm{SiMe}_{3}\right)_{2}\right\}_{2}\right)\right]_{2}(\mathbf{3})$. Ellipsoids at the $50 \%$ probability level. $\mathrm{H}$ atoms (other than $\mathrm{BCH}$ ) omitted for clarity. Selected bond lengths $(\AA)$ and angles $\left({ }^{\circ}\right)$ : Ba1-O1 $=2.3999(14)$, $\mathrm{Ba} 1-\mathrm{N} 1=2.7210(16), \mathrm{Ba} 1-\mathrm{N} 1^{\mathrm{i}}=2.8912(17), \mathrm{O} 1-\mathrm{B} 1=1.332(3)$; $\mathrm{O} 1-\mathrm{Ba} 1-\mathrm{N} 1$ $=121.64(5), \mathrm{O} 1-\mathrm{Ba} 1-\mathrm{N} 1^{\mathrm{i}}=144.18(5), \mathrm{N} 1-\mathrm{Ba} 1-\mathrm{N} 1^{\mathrm{i}}=82.34(5), \mathrm{B} 1-\mathrm{O} 1-\mathrm{Ba} 1=$ $160.00(14), \mathrm{O} 1-\mathrm{B} 1-\mathrm{C} 8=123.38(18), \mathrm{O} 1-\mathrm{B} 1-\mathrm{C} 7=120.05(18), \mathrm{C} 8-\mathrm{B} 1-\mathrm{C} 7=$ $116.57(17)$.

The molecular structure of 2 (Figures 2 and 3 ) depicts an unprecedented two-coordinate barium complex. The $\mathrm{Ba}-\mathrm{O}$

interatomic distances in $2(2.384(2)$ and $2.410(2) \AA)$ match that in $3(2.400(2) \AA)$. The O1-Ba1-O21 angle of $130.59(6)^{\circ}$ is far from the ideal linear geometry. This likely results from multiple $\mathrm{Ba} \cdots \mathrm{H}_{3} \mathrm{C}$ intramolecular (4) and intermolecular (4) agostic interactions with methyl groups from neighboring $\mathrm{SiMe}_{3}$ moieties (Figure 3). The corresponding eight $\mathrm{Ba} 1-\mathrm{H}$ distances range within 2.799(3)-3.119(3) $\AA_{;}^{[26]}$ the Ba-C distances to the carbon atoms bearing the relevant hydrogens are in the range 3.258(3)$3.886(3) \AA$. The relatively narrow angles $\mathrm{B} 2-\mathrm{O} 1-\mathrm{Ba} 1$ $\left(162.85(16)^{\circ}\right)$ and $\mathrm{B} 22-\mathrm{O} 21-\mathrm{Ba} 1\left(156.46(15)^{\circ}\right)$ testify to a limited contribution of the lone pairs on the $\mathrm{O}$ atoms to the $\mathrm{Ba}-\mathrm{O}$ and $\mathrm{B}-\mathrm{O}$ bonds.

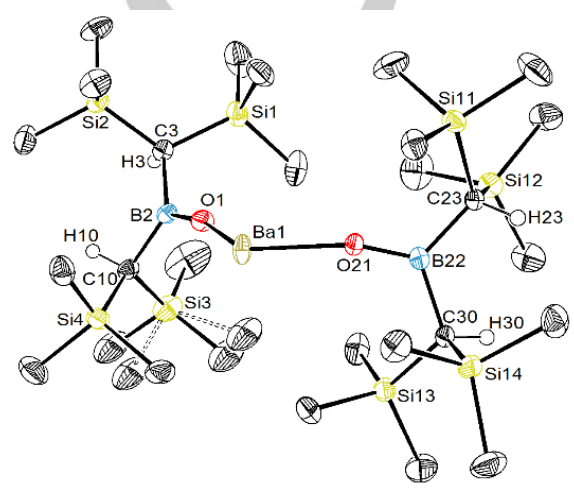

Figure 2. ORTEP representation of $\left[\mathrm{Ba}\left(\mathrm{OB}\left\{\mathrm{CH}\left(\mathrm{SiMe}_{3}\right)_{2}\right\}_{2}\right)_{2}\right]$ (2). Ellipsoids at the $50 \%$ probability level. Minor components in disordered Me groups shown in dotted bonds. $\mathrm{H}$ atoms (other than $\mathrm{BCH}$ ) and $\mathrm{Ba} \cdots \mathrm{H}_{3} \mathrm{C}$ interactions omitted for clarity. Selected bond lengths $(\AA)$ and angles $\left({ }^{\circ}\right): B a 1-01=2.3842(16)$, $\mathrm{Ba} 1-\mathrm{O} 21=2.4098(16), \quad \mathrm{O} 1-\mathrm{B} 2=1.333(3), \quad \mathrm{O} 21-\mathrm{B} 22=1.331(3) ;$ $\mathrm{O} 1-\mathrm{Ba} 1-\mathrm{O} 21=130.59(6), \mathrm{B} 2-\mathrm{O} 1-\mathrm{Ba} 1=162.85(16), \mathrm{B} 22-\mathrm{O} 21-\mathrm{Ba} 1=$ 156.46(15), O1-B2-C3 = 120.70(2), O1-B2-C10 = 120.10(2), C3-B2-C10 = $119.20(2), \mathrm{O} 21-\mathrm{B} 22-\mathrm{C} 23=121.00(2), \mathrm{O} 21-\mathrm{B} 22-\mathrm{C} 30=120.30(2)$, $\mathrm{C} 23-\mathrm{B} 22-\mathrm{C} 30=118.71(19)$

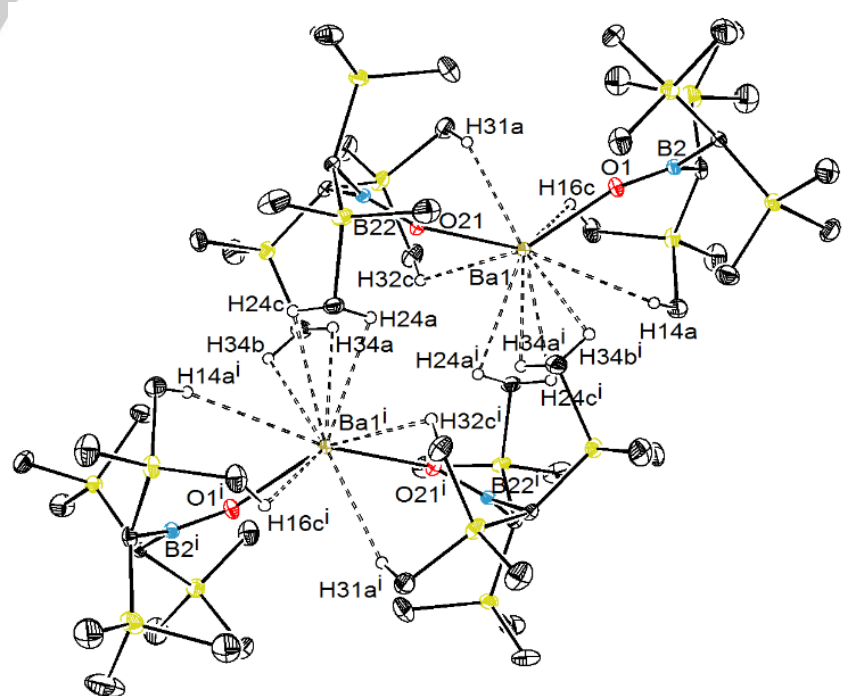

Figure 3. Representation of the molecular structure of $\left[\mathrm{Ba}\left(\mathrm{OB}\left\{\mathrm{CH}\left(\mathrm{SiMe}_{3}\right)_{2}\right\}_{2}\right)_{2}\right]$ (2), showing the pattern of eight $\mathrm{Ba} \cdots \mathrm{H}_{3} \mathrm{C}$ intra- and intermolecular interactions in dotted lines. $\mathrm{H}$ atoms other than those interacting with $\mathrm{Ba}$ are omitted for clarity. Only the main component of the disordered $\mathrm{SiMe}_{3}$ fragment is depicted. Pertaining Ba-H interatomic distances $(\AA)$ : Ba1-H14A = 3.119(3), Ba1-H16C 
$=2.932(3), \mathrm{Ba} 1-\mathrm{H} 31 \mathrm{~A}=2.799(3), \mathrm{Ba} 1-\mathrm{H} 32 \mathrm{C}=2.998(3), \mathrm{Ba} 1-\mathrm{H} 24 \mathrm{~A}^{\prime}=$

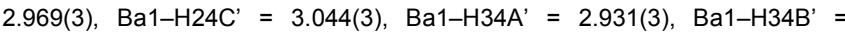
$2.957(3)$

State-of-the-art DFT computations ${ }^{[27]}$ have been employed to further characterise the bonding pattern in 2 and $\mathbf{3}$. Natural Population Analysis (NPA) and Bader's quantum theory of atoms in molecules (QTAIM) methodology have been applied. As far as the bonding situation in the rhomboidal $\mathrm{Ba}_{2} \mathrm{~N}_{2}$ central unit in $\mathbf{3}$ is concerned, QTAIM succeeded in locating bonding paths connecting barium with $\mathrm{N}_{\text {amide }}$ and $\mathrm{O}_{\text {boryloxide }}$ featuring bond critical points (BCPs) that are shifted towards the electropositive alkaline earth. The QTAIM topological parameter, viz. electron density $\rho(r)$ and its second derivative, the Laplacian $\nabla^{2} \rho(r)$, derived at the located BCPs are particularly informative. As detailed in Figure 4, $\rho(r)$ values are rather small $\left(\sim 0.03 e \AA^{-3}\right)$ with $\nabla^{2} \rho(r)$ adopting a positive sign. All this is indicative of the predominant electrostatic nature of $\mathrm{Ba}-\mathrm{N}$ and $\mathrm{B}-\mathrm{O}$ bonds, which are also considerably polarised. The likelihood for forming a dimer featuring a $\mathrm{Ba}_{2} \mathrm{O}_{2}$ central unit has also been probed. The corresponding $\mu-\mathrm{OBR}_{2}$ bridged compound 3' exhibits similar topological QTAIM parameter but is found $5.3 \mathrm{kcal} \mathrm{mol}^{-1}$ above 3 . In light of the primarily electrostatic bonding situation, the lower ability of 3' to involve bridging across a more electron deficient Oboryloxide becomes understandable, while steric crowding inflicted by the bulky boryloxide also plays a role.

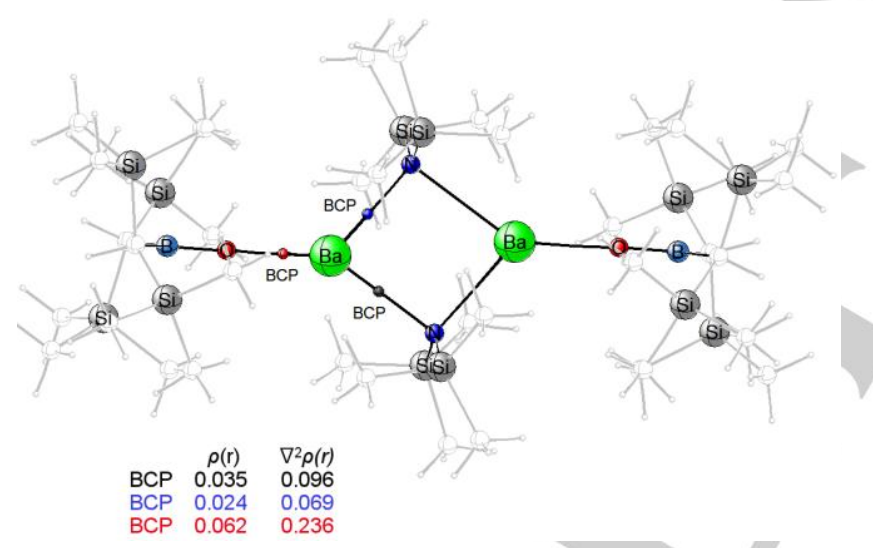

Figure 4. Topological QTAIM parameter (electron density $\rho(r)$ in $\mathrm{e}^{-3}$ and its Laplacian $\nabla^{2} \rho(r)$ in e $\left.\AA^{-5}\right)$ of crucial bond critical points (BCP) located for $\left[\mathrm{Ba}\left\{\mu^{2}\right.\right.$ $\left.\left.\mathrm{N}\left(\mathrm{SiMe}_{3}\right)_{2}\right\}\left(\mathrm{OB}\left\{\mathrm{CH}\left(\mathrm{SiMe}_{3}\right)_{2}\right\}_{2}\right)\right]_{2}(3)$.

The stabilising influence of $\mathrm{Ba}^{\prime \prime} \mathrm{H}_{3} \mathrm{C}$ interactions in 2 has been probed first by means of QTAIM. Unfortunately, a bonding path describing such interaction could not be found. ${ }^{[28]}$ It prompted us to evaluate to what degree dispersive forces influence the energy gap between 2 with a bent $\mathrm{O}-\mathrm{Ba}-\mathrm{O}$ unit and hypothetical 2' featuring a linear $\mathrm{O}-\mathrm{Ba}-\mathrm{O}$ alignment, which thus is less prone to $\mathrm{Ba}^{\cdots} \mathrm{H}_{3} \mathrm{C}$ interactions. Employing DFT with and without dispersion corrections revealed a widening of the gap by about two thirds due to an increased stability of 2 by dispersive interactions. It let us reasonably conclude that Ba" $\mathrm{H}_{3} \mathrm{C}$ interactions are likely vital for the stability of 2 .
Complexes 2, 2.(thf) $)_{2}$ and 3, as well as the bis-amide 1, catalyze the dehydrocoupling of $\mathrm{R}_{2} \mathrm{BOH}$ and hydrosilanes. The coupling with $\mathrm{PhSiH}_{3}$ in $\mathrm{C}_{6} \mathrm{D}_{6}$ at $60{ }^{\circ} \mathrm{C}$ produced the borasiloxane $\mathrm{PhSi}(\mathrm{H})_{2} \mathrm{OBR}_{2}\left(\mathbf{P}_{\mathbf{1}}\right)$ in high yields, and conversion was monitored by NMR spectroscopy. The thf-free dimer $\left[\mathrm{Ba}\left\{\mathrm{N}\left(\mathrm{SiMe}_{3}\right)_{2}\right\}_{2}\right]_{2}$ also generates $\mathbf{P}_{\mathbf{1}}$, but it is much too fast to enable reliable kinetic monitoring; yet, although we excluded it from our kinetic investigations for practical reasons, this precatalyst constitutes per se the most synthetically effective precatalyst for $\mathrm{BO}-\mathrm{H} / \mathrm{H}-\mathrm{Si}$ dehydrocouplings. For each of the four precatalysts, the semi-logarithmic plots of $\mathrm{PhSiH}_{3}$ conversion vs. time is linear, indicating a first-order dependence in $\left[\mathrm{PhSiH}_{3}\right]$. The respective apparent rate constants $k_{\text {app }}$ were of the same magnitude $\left(k_{\text {app }}: 1,2.19(5) \mathrm{h}^{-1} ; 2,0.64(1) \mathrm{h}^{-1} ; 2 \text {. (thf }\right)_{2}$, $0.52(1) h^{-1} ; 3,1.18(1) h^{-1}$ ), establishing about equal proficiency for all precatalysts, and indicating that $[\mathrm{Ba}]-\mathrm{OBR}_{2}$ species are involved in the catalytic manifold. Upon addition of 1 or even 2 equiv of $\mathrm{HN}\left(\mathrm{SiMe}_{3}\right)_{2}$ vs. Ba, the reaction rates for 2.(thf $)_{2}$ $\left(0.45(1)\right.$ and $0.57(1) \mathrm{h}^{-1}$ ) remained near identical to those of 2 and 2.(thf) $)_{2}$ alone, i.e. about 4 -fold lower than that of $1 .{ }^{[29]}$ The easily accessed and most active $\mathbf{1}$ was selected for further kinetic studies. First order dependence in $\left[\mathrm{PhSiH}_{3}\right]$ was confirmed by the linear plot of $\ln \left(R_{0}\right)$ vs. $\ln \left(\left[\mathrm{PhSiH}_{3}\right]_{0}\right)$, where $R_{0}$ is the initial rate, for a range of initial concentrations $\left[\mathrm{PhSiH}_{3}\right]_{0}$. The reaction rate is zeroth order in $\left[\mathrm{R}_{2} \mathrm{BOH}\right]$. It shows an unusual second order dependence in precatalyst concentration, ${ }^{[30]}$ as evidenced by the linear variations of $\ln \left(k_{\text {app }}\right)$ vs. $\ln ([1])$ (slope $=2$ ) and of $k_{\text {app }}$ vs. [1] $]^{2}$, and further corroborated by Burés' graphical method. ${ }^{[31]}$ The kinetic rate law for the coupling of $\mathrm{R}_{2} \mathrm{BOH}$ and $\mathrm{PhSiH}_{3}$ mediated by 1 is hence expressed by:

$$
R=-\mathrm{d}\left[\mathrm{PhSiH}_{3}\right] / \mathrm{d} t=k \cdot[1]^{2} \cdot\left[\mathrm{PhSiH}_{3}\right]
$$

where $k$ is the rate constant. These data are consistent with a catalytic cycle that evolves through a dinuclear transition state. Eyring analysis $\left(\mathrm{T}^{\mathrm{re}}=20-70^{\circ} \mathrm{C}\right)$ shows the reaction is kinetically facile, with $\Delta H^{\ddagger}=9.1(2) \mathrm{kcal} \mathrm{mol}^{-1}, \Delta S^{\ddagger}=-24.2(8) \mathrm{cal} \mathrm{mol}^{-1} \mathrm{~K}^{-1}$ indicative of a highly ordered transition state, and $\Delta G^{\ddagger}=16.4(5)$ $\mathrm{kcal} \mathrm{mol}{ }^{-1}$ at $25{ }^{\circ} \mathrm{C}$. Under otherwise identical conditions, reaction rates decrease upon ascending group 2 for the congeneric precatalysts $\left.1, \quad\left[\mathrm{Sr}\left\{\mathrm{N}\left(\mathrm{SiMe}_{3}\right)_{2}\right\}_{2} \text {. (thf }\right)_{2}\right]$ and $\left.\left[\mathrm{Ca}\left\{\mathrm{N}\left(\mathrm{SiMe}_{3}\right)_{2}\right\}_{2} \text {. (thf }\right)_{2}\right] \quad\left(k_{\mathrm{app}}=2.19(5) \mathrm{h}^{-1}, 1.80(1) \mathrm{h}^{-1}\right.$ and $0.082(1) h^{-1}$, respectively), although the drop is more appreciable for $\mathrm{Ca}$ than for $\mathrm{Sr}$.

Substrate scope was probed by tuning the nature of the hydrosilane coupled to $\mathrm{R}_{2} \mathrm{BOH}$ in reactions catalyzed by 1 (Table 1). In the benchmark coupling of $\mathrm{PhSiH}_{3}$ and $\mathrm{R}_{2} \mathrm{BOH}$, product $\mathbf{P 1}$ was produced in $100 \%$ and $75 \%$ yields in $10 \mathrm{~h}$ using respectively 2 and $1 \mathrm{~mol}-\%$ of precatalyst (entries 1 and 2$)$. The production of $\mathbf{P}_{1}$ is chemoselective, as the formation of $\mathrm{PhSi}(\mathrm{H})\left(\mathrm{OBR}_{2}\right)_{2}$ was never detected. Catalysis does not proceed with $\mathrm{Ph}_{2} \mathrm{SiH}_{2}$ (entry 6). This is due to the identity of the substrate rather than catalyst decomposition, since quantitative formation of $\mathbf{P}_{\mathbf{1}}$ was observed in a separate experiment where $\mathrm{PhSiH}_{3}$ was added to the NMR tube $12 \mathrm{~h}$ after the initial addition of $\mathrm{Ph}_{2} \mathrm{SiH}_{2}$ Similarly, coupling does not occur between $\mathrm{Ph}_{3} \mathrm{SiH}$ and $\mathrm{R}_{2} \mathrm{BOH}$. Commercially available alkoxyhydrosilanes (entry 7 ) and alkylhydrosilanes (entry 8) can be converted effectively, albeit the reactions are slower with these substrates. Compared to 
$\mathrm{PhSiH}_{3}$ (entry 2, $k_{\text {app }}=1.05(1) \mathrm{h}^{-1}$ ), reaction rates increase upon introduction of electron-withdrawing group in para position of the aromatic group (entries 3 and $4 ; k_{\mathrm{app}}=1.67(2) \mathrm{h}^{-1}$ ), whereas electron-donating groups inhibit the reaction (entry $5 ; k_{\text {app }}=$ $0.72(1) h^{-1}$ ); these observations agree with the accumulation of a partial negative charge localized at silicon in the turnoverlimiting step.

Table 1. Ba-catalysed dehydrocoupling of $\mathrm{R}_{2} \mathrm{BOH}$ and $\mathrm{SiHR}^{1} \mathrm{R}^{2} \mathrm{R}^{3 \text { [a] }}$

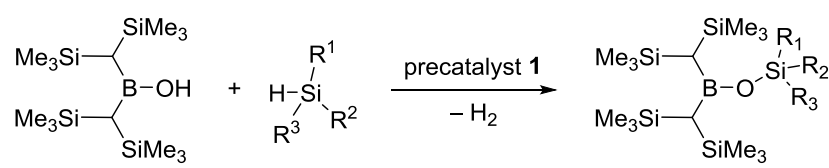

\begin{tabular}{|c|c|c|c|c|}
\hline & Silane & {$[\mathrm{OH}] /[\mathrm{SiH}] /[1]^{[\mathrm{b}]}$} & Product & Conv $[\%]^{[\mathrm{c}]}$ \\
\hline 1 & $\mathrm{PhSiH}_{3}$ & $50: 50: 1$ & $\mathrm{R}_{2} \mathrm{BO}-\mathrm{SiH}_{2} \mathrm{Ph}$ & 100 \\
\hline 2 & $\mathrm{PhSiH}_{3}$ & $100: 100: 1$ & $\mathrm{R}_{2} \mathrm{BO}-\mathrm{SiH}_{2} \mathrm{Ph}$ & 75 \\
\hline 3 & $\begin{array}{l}p-\mathrm{F}_{-}-\mathrm{C}_{6} \mathrm{H}_{4-} \\
\mathrm{SiH}_{3}\end{array}$ & $50: 50: 1$ & $\begin{array}{l}\mathrm{R}_{2} \mathrm{BO}- \\
\mathrm{SiH}_{2}\left(p-\mathrm{F}-\mathrm{C}_{6} \mathrm{H}_{4}\right)\end{array}$ & 100 \\
\hline 4 & $\begin{array}{l}p-\mathrm{F}_{-} \mathrm{C}_{6} \mathrm{H}_{4}^{-} \\
\mathrm{SiH}_{3}\end{array}$ & $100: 100: 1$ & $\begin{array}{l}\mathrm{R}_{2} \mathrm{BO}- \\
\mathrm{SiH}_{2}\left(p-\mathrm{F}-\mathrm{C}_{6} \mathrm{H}_{4}\right)\end{array}$ & 86 \\
\hline 5 & $\begin{array}{l}p-\mathrm{MeO}-\mathrm{C}_{6} \mathrm{H}_{4}- \\
\mathrm{SiH}_{3}\end{array}$ & $100: 100: 1$ & $\begin{array}{l}\mathrm{R}_{2} \mathrm{BO}- \\
\mathrm{SiH}_{2}\left(p-\mathrm{MeO}-\mathrm{C}_{6} \mathrm{H}_{4}\right)\end{array}$ & 63 \\
\hline 6 & $\mathrm{Ph}_{2} \mathrm{SiH}_{2}{ }^{[\mathrm{d}]}$ & $10: 10: 1$ & $\mathrm{R}_{2} \mathrm{BO}-\mathrm{SiHPh}_{2}$ & 0 \\
\hline 7 & $\left({ }^{i} \mathrm{PrO}\right)_{3} \mathrm{SiH}^{[\mathrm{d}]}$ & $10: 10: 1$ & $\mathrm{R}_{2} \mathrm{OB}-\mathrm{Si}\left(\mathrm{O}^{\prime} \mathrm{Pr}\right)_{3}$ & 62 \\
\hline 8 & ${ }^{n} \mathrm{BuSiH}_{3}^{[e]}$ & $10: 10: 1$ & $\mathrm{R}_{2} \mathrm{OB}-\mathrm{SiH}_{2}{ }^{n} \mathrm{Bu}$ & 89 \\
\hline
\end{tabular}

[a] Reactions at $60{ }^{\circ} \mathrm{C}$ in $\mathrm{C}_{6} \mathrm{D}_{6}(0.6 \mathrm{~mL})$, with $[1]_{0}=1.69-16.9 \mathrm{mM}$; reaction times (10 $\mathrm{h}$ unless otherwise specified) not optimized. [b] Initial ratio $\left[\mathrm{R}_{2} \mathrm{BOH}\right]_{0} /\left[\mathrm{SiHR}^{1} \mathrm{R}^{2} \mathrm{R}^{3}\right]_{0} /[1]_{0}$. [c] Conversion of $H \mathrm{HSiR}^{1} \mathrm{R}^{2} \mathrm{R}^{3}$ evaluated by ${ }^{1} \mathrm{H}$ NMR spectroscopy, using $\mathrm{C}_{6} \mathrm{Me}_{6}$ as internal calibrant. [d] Reaction time $=12$ h. [e] Reaction time $=48 \mathrm{~h}$; conversion reached $70 \%$ after $24 \mathrm{~h}$.

In conclusion, $\left\{\left(\mathrm{Me}_{3} \mathrm{Si}\right)_{2} \mathrm{CH}\right\}_{2} \mathrm{BO}^{-}$enables the syntheses of discrete barium-boryloxide complexes featuring the lowest coordination numbers for $\mathrm{Ba}$. Computational analysis revealed the primarily electrostatic nature of considerably polarised $\mathrm{B}-$

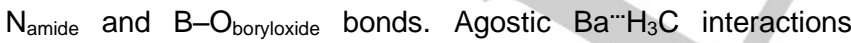
appear instrumental for stabilizing those seemingly coordinatively unsaturated complexes. These compounds are the first molecular catalysts to produce borasiloxanes by dehydrocoupling of borinic acids and hydrosilanes, and we are now working on expanding substrate scope to other such reagents. For instance, the coupling of $\mathrm{PhSiH}_{3}$ with the bulky $\left\{2,4,6-{ }^{i} \mathrm{Pr}_{3}-\mathrm{C}_{6} \mathrm{H}_{2}\right\}_{2} \mathrm{BOH}$ is mediated by $\mathbf{1}$ and 2 , albeit the reactions appear to be slower than with $\mathrm{R}_{2} \mathrm{BOH}$ (e.g. $37 \%$ conversion to $\left\{2,4,6-{ }^{i} \mathrm{Pr}_{3}-\mathrm{C}_{6} \mathrm{H}_{2}\right\}_{2} \mathrm{BO}-\mathrm{SiH}_{2} \mathrm{Ph}$ is reached after $24 \mathrm{~h}$ at $60{ }^{\circ} \mathrm{C}$ with $\left.[\mathrm{OH}] /[\mathrm{SiH}] /[\mathrm{Ba}]=10: 10: 1\right)$. On the other hand, with less bulky substrates such as $\mathrm{Mes}_{2} \mathrm{BOH}$, catalysis is for now plagued by the appearance of catalytically inert $\mathrm{B}-\mathrm{O}-\mathrm{B}$ containing species, e.g. $\mathrm{Mes}_{2} \mathrm{~B}-\mathrm{O}-\mathrm{BMes}_{2}$ (Mes = mesityl). The catalyzed formation of $\mathbf{P}_{\mathbf{1}}$ is overall kinetically affordable, and we are endeavoring to elucidate the catalytic manifold entwined to the kinetic rate law given by equation (1). In particular, the very negative entropy of activation is compatible with a very organized transition state resulting from nucleophilic attack of the metal-bound oxygen atom onto the incoming silane, much as that seen in the barium-catalyzed dehydrocoupling of amines and hydrosilanes; ${ }^{[32]}$ yet, a simpler $\sigma$-bond insertive mechanism cannot be excluded at this stage. All these results will be detailed in a forthcoming report.

Keywords: Barium • boryloxide • low-coordinate complex • dehydrocoupling catalysis $\cdot$ borasiloxane

[1] a) S. Harder, Chem. Rev. 2010, 110, 3852-3876; b) M. S. Hill, D. J. Liptrot, C. Weetman, Chem. Soc. Rev. 2016, 45, 972-988.

[2] M. Westerhausen, A. Koch, H. Görls, S. Krieck, Chem. Eur. J. 2017, 23 1456-1483.

[3] a) R. Fischer, M. Gärtner, H. Görls, M. Westerhausen, Angew. Chem. Int. Ed. 2006, 45, 609-612; b) S. Harder, J. Brettar, Angew. Chem. Int Ed. 2006, 45, 3474-3478; c) A. S. S. Wilson, M. S. Hill, M. F. Mahon, C. Dinoi, L. Maron, Science 2017, 358, 1168-1171.

[4] D. Mukherjee, D. Schuhknecht, J. Okuda, Angew. Chem. Int. Ed. 10.1002/anie.201801869.

[5] a) B. Maitland, M. Wiesinger, J. Langer, G. Ballmann, J. Pahl, H. Elsen, C. Färber, S. Harder, Angew. Chem. Int. Ed. 2017, 56, 11880-11884 b) D. Mukherjee, T. Höllerhage, V. Leich, T. P. Spaniol, U. Englert, L. Maron, J. Okuda, J. Am. Chem. Soc. 2018, 140, 3403-3411.

[6] a) X. Shi, C. Hou, C. Zhou, Y. Song, J. Cheng, Angew. Chem. Int. Ed. 2017, 56, 16650-16653; b) M. Wiesinger, B. Maitland, C. Färber, G. Ballmann, C. Fischer, H. Elsen, S. Harder, Angew. Chem. Int. Ed. 2017, 56, 16654-16659.

[7] Y. Sarazin, J.-F. Carpentier, Chem. Rec. 2016, 16, 2482-2505.

[8] W. D. Buchanan, D. G. Allis, K. Ruhlandt-Senge, Chem. Commun. 2010, 46, 4449-4465.

[9] K. G. Caulton, M. H. Chisholm, S. R. Drake, K. Folting, J. Chem. Soc., Chem. Commun. 1990, 1349-1351.

[10] O. Poncelet, L. G. Hubert-Pfalzgraf, L. Toupet, J.-C. Daran, Polyhedron 1991, 10, 2045-2050.

[11] S. R. Drake, W. E. Streib, K. Folting, M. H. Chisholm, K. G. Caulton, Inorg. Chem. 1992, 31, 3205-3210.

[12] J. Utko, S. Szafert, L. B. Jerzykiewicz, P. Sobota, Inorg. Chem. 2005, 44, 5194-5196.

[13] W. D. Buchanan, M. A. Guino-o, K. Ruhlandt-Senge, Inorg. Chem. 2010, 49, 7144-7155.

[14] W. A. Wojtczak, M. J. Hampden-Smith, E. N. Duesler, Inorg. Chem 1996, 35, 6638-6639.

[15] P. Shao, D. J. Berg, G. W. Bushnell, Can. J. Chem. 1995, 73, 797-803.

[16] J. A. Darr, S. R. Drake, D. J. Williams, A. M. Z. Slawin, J. Chem. Soc., Chem. Commun. 1993, 866-868.

[17] M. P. Coles, Coord. Chem. Rev. 2016, 323, 52-59.

[18] S. C. Cole, M. P. Coles, P. B. Hitchcock, Organometallics 2004, 23 , 5159-5168.

[19] R. Pena-Alonso, G. Mariotto, C. Gervais, F. Babonneau, G. D. Soraru, Chem. Mater. 2007, 19, 5694-5702.

[20] a) W. Liu, M. Pink, D. Lee, J. Am. Chem. Soc. 2009, 131, 8703-8707.

[21] a) D. A. Foucher, A. J. Lough, I. Manners, Inorg. Chem. 1992, 31, 3034-3043; b) K. L. Fujdala, A. G. Oliver, F. J. Hollander, T. D. Tilley, Inorg. Chem. 2003, 42, 1140-1150; c) M. Pascu, A. Ruggi, R. Scopelliti, K. Severin, Chem. Commun. 2013, 49, 45-47.

[22] a) B. Marciniec, J. Walkowiak, Chem. Commun. 2008, 2695-2697; b) B. Chatterjee, C. Gunanathan, Chem. Commun. 2017, 53, 2515-2518; c) A. Yoshimura, M. Yoshinaga, H. Yamashita, M. Igarashi, S. Shimada, K. Sato, Chem. Commun. 2017, 53, 5822-5825.; d) A. Dhakshinamoorthy, A. M. Asiri, P. Concepcion, H. Garcia, Chem. Commun. 2017, 53, 9998-10001. 
[23] M. Ito, M. Itazaki, H. Nakazawa, J. Am. Chem. Soc. 2014, 136, 61836186.

[24] a) B. A. Vaartstra, J. C. Huffman, W. E. Streib, K. G. Caulton, Inorg. Chem. 1991, 30, 121-125; b) A. G. M. Barrett, M. R. Crimmin, M. S. Hill, G. Kociok-Köhn, D. J. MacDougall, M. F. Mahon, Pa. A. Procopiou, Organometallics 2008, 27, 3939-3946.

[25] J. S. Alexander, K. Ruhlandt-Senge, Angew. Chem. Int. Ed. 2001, 40, 2658-2660.

[26] The next closest Ba $\cdots H$ interatomic distance of $3.214(3) \AA$ is too long for a significant interaction

[27] DFT calculations were performed at the B97-D3/def2-TZVP2 level of theory. See the SI for more details.

[28] Agostic interactions sometimes are rather difficult to pin down unequivocally within the QTAIM framework. See M. Lein, Coord. Chem. Rev. 2009, 253, 625-634 for further reference. Moreover, the absence of a bonding path does not necessarily prove the non-existence of a stabilising agostic interaction

[29] The reaction rate for the iminoanilido $\left[\left\{\mathrm{N}^{\wedge} \mathrm{N}\right\} \mathrm{Ba}\left\{\mathrm{N}\left(\mathrm{SiMe}_{3}\right)_{2} \text {. (thf }\right)_{2}\right]$ (B. Liu, T. Roisnel, J.-F. Carpentier, Y. Sarazin, Angew. Chem. Int. Ed. 2012 51, 4943-4946), 0.62(1) $\mathrm{h}^{-1}$, equalled those for 2 and 2.(thf) $)_{2}$. Under catalytic conditions, the basic $\left\{\mathrm{N}^{\wedge} \mathrm{N}\right\}^{-}$reacts with $\mathrm{R}_{2} \mathrm{BOH}$ to generate a complex akin to 1, 2.(thf) $)_{2}$ or 3. Full release of $\left\{\mathrm{N}^{\wedge} \mathrm{N}\right\} \mathrm{H}$ was detected by NMR upon reaction of $\left[\left\{\mathrm{N}^{\wedge} \mathrm{N}\right\} \mathrm{Ba}\left\{\mathrm{N}\left(\mathrm{SiMe}_{3}\right)_{2} \text {. (thf }\right)_{2}\right]$ and 5 equiv of $\mathrm{R}_{2} \mathrm{BOH}$ in $\mathrm{C}_{6} \mathrm{D}_{6}$.

[30] M. S. Hill, D. J. Liptrot, D. J. MacDougall, M. F. Mahon, T. P. Robinson, Chem. Sci. 2013, 4, 4212-4222.

[31] J. Burés, Angew. Chem. Int. Ed. 2016, 55, 2028-2031.

[32] C. Bellini, J.-F. Carpentier, S. Tobisch, Y. Sarazin, Angew. Chem. Int Ed. 2015, 


\section{Entry for the Table of Contents}

\section{COMMUNICATION}

The first soluble barium boryloxides have been structurally

characterized, and they are shown to act as competent molecular catalysts for the dehydrocoupling of borinic acids with hydrosilanes to generate borasiloxanes under mild conditions.

BORASILOXANE dehydrocoupling catalysis

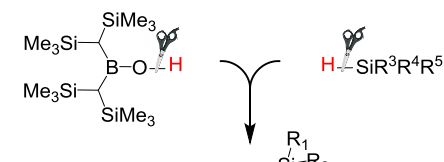

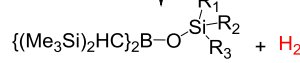

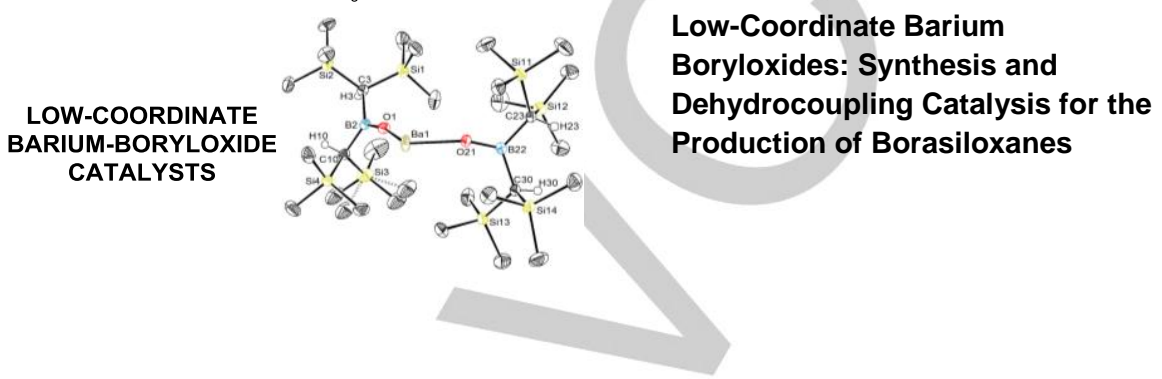

E. Le Coz, V. Dorcet, T. Roisnel, S. Tobisch, * J.-F. Carpentier, and $Y$. Sarazin*

Page No. - Page No.

Low-Coordinate Barium

Boryloxides: Synthesis an

Dehydrocoupling Catalysis for the UM-BORYLOXIDE CATALYSTS

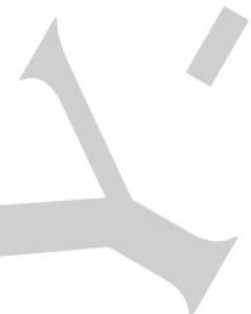

